Annals of Plant and Soil Research 23(2): 192-195 (2021)

https://doi.org/10.47815/apsr.2021.10055

\title{
Effect of moisture conservation practices on growth and yield of Indian mustard and chickpea intercropping system under rainfed conditions
}

\author{
ANJIR KUMARI PANDEY*, B.S. KASANA AND K.N. NAMDEO**
}

Department of Agronomy, RMSKVV, College, Gwalior (M.P.) 474002

Received: March, 2021; Revised accepted: April, 2021

\begin{abstract}
A field experiment was conducted during winter season of 2018-19 and 2019-20 at the Research Farm, College of Agriculture, Gwalior (M.P.) to study the effect of moisture conservation practices on Indian mustard-chickpea intercropping under rainfed conditions. The treatments comprised of four intercropping systems and four moisture conservation practices were evaluated in split plot design with three replications. The results revealed that intercropping of mustard + chickpea at1:4 and 2:4 row ratios registered maximum growth parameters, yield and yield-attributes and economics of both the crops over chickpea or mustard grown alone. LER was 1.43 to 1.44. Mustard equivalent yield was 23.05 to $24.21 \mathrm{~g} / \mathrm{ha}$ over sole chickpea (21.95 q ha $\left.{ }^{1}\right)$ and sole mustard (13.54 q ha $\left.{ }^{-1}\right)$.Weed mulching @ $5 t$ ha ${ }^{-1}$ resulted in higher growth, yield and yieldattributes and economics as compared to soil or paddy straw mulching.
\end{abstract}

Key words: Intercropping, mulching, chickpea, yield-attributes, mustard

\section{INTRODUCTION}

Intercropping system is much more scientific, rational and refined concept than traditional practice of mixed cropping. Cultivation of Indian mustard (Brassica juncea) as an intercrop in chickpea (Cicer arietinum) is common in India under rainfed conditions. Such technology of intercropping increases the productivity per unit area per unit time. Under this situation, two crops of different root-shoot growing nature are grown at a certain proportion and row ratio. Thereby intercropping increases the cropping intensity, total productivity and profitability under efficient utilization of soil, water, nutrients and sunlight in time and space. Moisture conservation practices play the most important role when crops are grown totally under rainfed conditions. Mulching, antitranspirant etc. play significant role in the success of dryland agriculture. Organic mulches are poor conductor of heat that effectively reduce soil temperature and maintain residual soil moisture for a longer period. Regar et al. (2007) found that straw mulching (5 t/ha) significantly increased the seed yield of rainfed Indian mustard by $17.7 \%$ over no mulch with enhanced water use efficiency. Straw mulch slowed down the energy exchange at soil surface, thermal diffusion and provided treat insulation, making uniform soil temperature that minimized evaporation losses. Looking to all these facts, the present research was taken up to enhance the total productivity of the Indian mustard + chickpea intercropping system.

\section{MATERIALS AND METHODS}

The field experiment was conducted during winter season of 2018-19 and 2019-20 at the Research Farm, College of Agriculture, Gwalior (M.P.). The field soil was sandy-loam having $\mathrm{pH} 7.7$, electrical conductivity $0.16 \mathrm{dS} \mathrm{m}^{-}$ ${ }^{1}$, organic carbon $4.8 \mathrm{~g} \mathrm{~kg}^{-1}$, and available $\mathrm{N}$, $\mathrm{P}_{2} \mathrm{O}_{5}$ and $\mathrm{K}_{2} \mathrm{O} 219,16.5$ and $284 \mathrm{~kg} \mathrm{ha}^{-1}$, respectively. The treatments consisted of four intercropping systems (sole mustard, sole chickpea, mustard + chickpea 1:4 and 2:4 row ratios) in the main-plots and four moisture conservation practices (no mulch, soil, paddystraw and weed mulching) in the sub-plots. The treatments were laid out in split-plot design with three replications. The Indian mustard var. RVM-3 and chickpea var.RVG-2-2 were sown @ 5 and $80 \mathrm{~kg}$ seed ha ${ }^{-1}$, respectively keeping 30 $\mathrm{cm}$ row spacing. The crops were sown on 10 to 25 October and harvested on 26 to 31 March during 2018-19 and 2019-20, respectively. Fertilizers @ 60:30:20:20 kg ha ${ }^{-1}$ NPKS were applied to Indian mustard and 20:50:20:20 kg ha1 NPKS to chickpea. NPKS fertilizers were applied through urea, SSP, MOP and elemental 
sulphur, respectively. The crops were grown under rainfed conditions applying recommended package of practices. The winter rains received during the cropping season were 461.6 and $458.7 \mathrm{~mm}$ in 2018 and 2019, respectively. Land equivalent ratio and economics were determined treatment wise as per recommended procedures.

\section{RESULTS AND DISCUSSION}

\section{Growth parameters}

The scrutiny of data (Table 1) indicated that the intercropping of mustard + chickpea at $1: 4$ and $2: 4$ row ratios encouraged the plant height, branches/plant and DM accumulation/plant as compared to sole cropping. Such increase in growth parameters may be owing to the fact that all the universal benefits of legume and cover crop chickpea were availed by the adjustment mustard crop. Additional residual soil moisture and atmospheric fixed- $\mathrm{N}$ was available to the mustard crop. The findings confirm the observations of Kumar et al. (2012) and Lal et al.
(2015). The reduction in DM accumulation/plant of chickpea due to intercropping system was because of shading and competition for natural resources offered by mustard. This fact has also been supported by Lal et al (2014).

Amongst the organic mulches, weed mulching@ @ ha ${ }^{-1}$ performed the best in raising the growth parameters of both the crops. The second best was paddy straw mulching @ 5 t ha 1 . This was mainly due to increased soil moisture and essential nutrients during the active growth stage. This has resulted in the improvement in root growth, cell multiplication, elongation and cell expression in the plant body which ultimately increased the growth parameters. Weed mulch was found more beneficial than paddy straw mulch because of the differences in residual plant nutrition, percentage of moisture and mode of their application and decomposition. The beneficial influence of different types of mulches are in conformity with those reported by Lakhpale and Shrivastava (2006), Regar et al. (2007), Awasthi et al. (2007), Devi et al. (2014) and Lal et al. (2015).

Table 1: Growth and yield-attributes of mustard and chickpea as influenced by their intercropping systems and moisture conservation practices (Pooled of 2 seasons'

\begin{tabular}{|c|c|c|c|c|c|c|c|c|c|c|}
\hline \multirow[t]{2}{*}{ Treatments } & \multicolumn{2}{|c|}{$\begin{array}{c}\text { Plant } \\
\text { height }(\mathrm{cm})\end{array}$} & \multicolumn{2}{|c|}{$\begin{array}{l}\text { Branches/ } \\
\text { plant }\end{array}$} & \multicolumn{2}{|c|}{$\begin{array}{l}\text { Dry matter/plant } \\
\text { (g) }\end{array}$} & \multicolumn{2}{|c|}{\begin{tabular}{|c|} 
Siliquae /pods \\
/plant
\end{tabular}} & \multicolumn{2}{|c|}{$\begin{array}{l}\text { Seed/Siliqua } \\
\text { /pods }\end{array}$} \\
\hline & Mustard & Chickpea & Mustard & Chickpea & Mustard & Chickpea & Mustard & Chickpea & Mustard & Chickpea \\
\hline \multicolumn{11}{|c|}{ Intercropping systems } \\
\hline Sole mustard & 162.63 & -- & 12.74 & -- & 47.72 & -- & 301.00 & -- & 14.03 & -- \\
\hline Sole chickpea & -- & 55.50 & -- & 10.68 & -- & 5.96 & -- & 58.95 & -- & 1.19 \\
\hline $\begin{array}{l}\text { Mustard + chickpea } \\
(1: 4)\end{array}$ & 166.25 & 57.24 & 13.18 & 10.92 & 49.29 & 6.11 & 323.38 & 61.36 & 14.34 & 1.23 \\
\hline $\begin{array}{l}\text { Mustard + chickpea } \\
(2: 4)\end{array}$ & 170.88 & 58.99 & 14.09 & 11.33 & 50.00 & 6.33 & 339.75 & 63.40 & 14.76 & 1.27 \\
\hline $\begin{array}{l}\text { C.D. }(P=0.05) \\
\text { Moisture conservatic }\end{array}$ & 0.38 & 0.62 & 0.47 & 0.04 & 0.05 & 0.03 & 0.47 & 0.18 & 0.57 & 0.01 \\
\hline No mulch & 149.33 & 51.10 & 11.50 & 10.03 & 44.72 & 5.66 & 261.17 & 56.54 & 13.63 & 1.16 \\
\hline Soil mulch & 162.50 & 54.88 & 13.13 & 10.22 & 48.06 & 5.92 & 306.50 & 59.18 & 14.20 & 1.18 \\
\hline $\begin{array}{l}\text { Paddy straw mulch } \\
\text { ( } 5 \mathrm{t} / \mathrm{ha})\end{array}$ & 174.00 & 59.75 & 13.92 & 11.31 & 50.47 & 6.29 & 344.33 & 62.39 & 14.60 & 1.27 \\
\hline $\begin{array}{l}\text { Weed mulch (5 } \\
\text { t/ha) }\end{array}$ & 180.50 & 63.24 & 14.80 & 12.36 & 52.75 & 6.68 & 373.50 & 66.83 & 15.07 & 1.30 \\
\hline$C D(P=0.05)$ & 7.02 & 2.16 & 0.56 & 0.68 & 1.15 & 0.08 & 14.53 & 1.22 & 0.16 & 0.03 \\
\hline Interaction & Sig. & Sig. & Sig. & Sig. & Sig. & Sig. & Sig. & Sig. & Sig. & Sig. \\
\hline
\end{tabular}

\section{Yield and yield-attributes}

The planting pattern of mustard + chickpea in different $(1: 4$ and $2: 4)$ row proportions augmented significantly higher growth and yield attributes than the sole cropping of both the crops. The increase in all these parameters might be owing to the nutrient 
sparing effect of leguminous chickpea. It is well evident that the atmospheric- $\mathrm{N}$ fixed by bacteria in root-nodules of chickpea import nitrogen enrichment to mustard grown in combination, thereby increasing the yield and yield attributes. Such intercropping increased nutrient absorption and large amount of multi-nutrients found in the seed and siliqua, which are considered essential for seed formation and boldness of seeds. This was because of vigorous root system for effective absorption of available nutrients from chickpea as a legume crop. The present findings are in consonance as found by Ravi Kumar et al. (2006), Kumar et al. (2012), Devi et al. (2014) and Lal et al. (2015).

Table 2: Yield-attributes, mustard equivalent yield and economics as influenced by their intercropping systems and moisture conservation practices (Pooled of 2 seasons)

\begin{tabular}{|c|c|c|c|c|c|c|c|c|}
\hline \multirow{2}{*}{ Treatments } & \multicolumn{2}{|c|}{ Test weight $(\mathrm{g})$} & \multicolumn{2}{|c|}{ Seed yield/plant $(\mathrm{g})$} & \multirow{2}{*}{$\mid \begin{array}{c}\text { Mustard } \\
\text { equivalent yield } \\
\text { (q/ha) }\end{array}$} & \multirow{2}{*}{$\begin{array}{l}\text { Land } \\
\text { equivalent } \\
\text { ratio }\end{array}$} & \multirow{2}{*}{$\begin{array}{c}\text { Net } \\
\text { income } \\
\text { (Rs.ha) }\end{array}$} & \multirow{2}{*}{$\begin{array}{l}\mathrm{B}: \mathrm{C} \\
\text { ratio }\end{array}$} \\
\hline & Mustard & Chickpea & Mustard & Chickpea & & & & \\
\hline \multicolumn{9}{|l|}{ Intercropping systems } \\
\hline Sole mustard & 4.10 & - & 13.98 & - & 13.54 & 1.00 & 30632 & 1.78 \\
\hline Sole chickpea & - & 25.91 & - & 12.25 & 21.95 & 1.00 & 73132 & 2.86 \\
\hline Mustard + chickpea (1:4) & 4.46 & 27.36 & 14.38 & 12.57 & 23.05 & 1.43 & 79010 & 3.00 \\
\hline Mustard + chickpea (2:4) & 4.65 & 27.95 & 15.06 & 13.25 & 24.21 & 1.44 & 84689 & 3.15 \\
\hline C.D. $(P=0.05)$ & 0.01 & 0.13 & 0.03 & 0.09 & 0.13 & 0.01 & & - \\
\hline No mulch & 3.97 & 24.95 & 13.08 & 11.83 & 18.90 & 1.21 & 60125 & 2.62 \\
\hline Soil mulch & 4.29 & 25.74 & 14.019 & 12.3 & 20.09 & 1.22 & 62982 & 2.57 \\
\hline Paddy straw mulch (5 t/ha) & 4.61 & 28.16 & 14.87 & 13.12 & 21.00 & 1.22 & 67673 & 2.69 \\
\hline Weed mulch (5 t/ha) & 4.75 & 29.44 & 15.73 & 13.43 & 22.78 & 1.22 & 76687 & 2.91 \\
\hline$C D(P=0.05)$ & 0.19 & 0.907 & 0.23 & 0.25 & 0.97 & NS & - & - \\
\hline Interaction & Sig. & Sig. & Sig. & Sig. & Sig. & NS & -- & - \\
\hline
\end{tabular}

The use of paddy straw or weed mulches as the moisture conserving practices resulted in almost significantly higher yield and yield attributes of both the crops over soil mulching or no mulching treatments. The favourable influence of mulches on growth attributes might be owing to efficient and greater partitioning of metabolites and adequate translocation of photosynthates to the developing reproductive structures. Similar results have also been reported by Regar et al. (2007), Agrawal and Agnihotri (2007), Awasthi et al. (2007), Devi et al. (2014) and Lal et al. (2015).

\section{Economics}

The intercropping of mustard + chickpea (1:4 and 2:4 row ratios) gave maximum net income (Rs. 79010 to Rs. 84689 /ha with 3.0 to $3.15 \mathrm{~B}: \mathrm{C}$ ratio) as compared to sole cropping mustard (Rs. 30632/ha) and chickpea (Rs. $73132 / \mathrm{ha}$ ). The weed mulching and paddy straw mulching recorded higher net income (Rs.76687 to Rs.67673/ha, respectively) as compared to soil mulching (Rs. 62982/ha) and no mulching (Rs. 60125/ha). The B:C ratios were 2.91, $2.69,2.57$ and 2.62 , respectively. The highest net income (Rs. 94071/ha) was achieved under mustard-chickpea (2:4) with weed mulching, followed by mustard + chickpea (1:4 row ratio).

The findings concluded that the adoption of mustard + chickpea in 2:4 row ratio alongwith weed or paddy straw mulching performed the best to enhance the total productivity and economical gain under the agro-climatic conditions of Gwalior region. 


\section{REFERENCES}

Agarwal, Mina and Agnihotri, A.K.(2007) Effect of straw incorporation on carbon and nitrogen mineralization. Annals of Plant and Soil Research, 9(2): 184-185.

Awasthi, U.D., Singh, R.B. and Dubey, S.D. (2007) Effect of sowing date and moisture conservation practice on growth and yield of Indian mustard varieties. Indian Journal of Agronomy, 52(2): 151153.

Devi, K.N., Shamurailatpam, D., Singh, N.B., Singh, N.G., Singh, L.N., Singh, A.D., Chanu, O.P.,Singh, S.R.,Devi,S.R. and Devi, L.S.(2014) Performance of lentil and mustard intercropping under rainfed condition. Australian Journal Crop Science, 8(2): 284-289.

Kumar, B.R.M., Mansur, C.P., Salimath, P.M. and Vishwanatha, S. (2012) Evaluation of different intercropping row proportions of chickpea with various rabi oilseed crops under rainfed condition. International Journal of Forestry and Crop Improvement, 3(2): 72-75.

Lal, B., Rana, K.S., Rana, Gautam Priyanka, Rana, D.S., Shivay, Y.S., Meena,
B.P.,Meena, R.K. and Singh, P. (2015) Ethiopian mustard-chickpea intercropping system is a viable option of yield advantage in dryland condition of north India-Part II. Proceedings of the National Academy of Sciences, India Section B:Biological Sciences, 86(3): 757-766.

Lal,B., Rana, K.S., Rana, D.S., Gautam, P., Shivay, Y.S.,Ansari, M.A., Meena, B.P.ad Kumar, K.(2014) Influence of intercropping, moisture conservation practice and $\mathrm{P}$ and $\mathrm{S}$ levels on growth, nodulation and yield of chickpea under rainfed condition. Legume Research, 37(3): 30-305.

Ravi Kumar, Ali, Masood, Arya, R.L. and Mishira, J.P. (2006) Enhancing productivity and profitability of chickpea + Indian mustard intercropping system. Indian Journal of Agronomy, 51(1): 27-30.

Regar, P.L., Rao, S.S. and Joshi, N.L. (2007) Effect of moisture conservation practices on productivity of rainfed Indian mustard. Indian Journal of Agronomy, 52(2): 148150. 